\title{
67-The portrayal of femininity and maternity in Mehmed, My Hawk and The Kalevala
}

\section{Serap SARIBAȘ}

APA: Sarıbaş, S. (2022). The portrayal of femininity and maternity in Mehmed, My Hawk and The Kalevala. RumeliDE Dil ve Edebiyat Araşttrmalar Dergisi, (26), 1074-1081. DOI: 10.29000/rumelide.1074524.

\begin{abstract}
Over the last few years there have been alterations in the construction of gender, particularly for women. The concepts of sex and gender are divided with sex remaining biological, and gender becoming constructed. The depiction of the ideal woman as passive, faithful, and obedient thus changed. As the gender issue reforms, motherhood has also begun to be questioned due to its association with the female sex. Women who meet these requirements are labelled "good" mothers, while those who do not are "bad". Such changes in gender and motherhood led to the distinct characterization of women in daily life and these women began to be portrayed in literature with a special emphasis on their newly constructed female images. Novels and plays that display the changing face of motherhood with careless, nasty and irresponsible mothers have also appeared. However, there are still literary works that represent a more traditional woman and mother. In literature, even the representation of traditional womanhood and motherhood differs since some writers use these women to reveal their weakness, oppression, and vulnerability while others use their literary ability to exhibit how a traditional woman and mother can be strong, dedicated and compassionate to her children. Elias Lönnrot, a well-known literary figure in Finland, with his epic compilation of national folklore, The Kalevala, and Yashar Kemal, one of the most noteworthy authors of Turkish literature, with his renowned Memed, My Hawk, unveil entirely divergent attitudes towards the identities of "woman" and "mother". The aim of this paper is to demonstrate how Kemal portrays womanhood and motherhood positively in Memed, My Hawk, while Lönnrot flaunts a dismissive viewpoint in The Kalevala. Analysis of these two masterpieces from disparate authors and epochs shows their distinctiveness in consideration of the Anatolian and Finnish cultures.
\end{abstract}

Keywords: Anatolian Culture, Finnish Folklore and Mythology, Female Characters

\section{Ince Memed romanında ve Kalevala destanında kadınlık ve annelik tasviri}

\author{
$\ddot{\mathbf{O z}}$
}

Son birkaç yılda, özellikle kadınlar için cinsiyetin inşasında değişiklikler olmuştur. Cinsiyet ve toplumsal cinsiyet kavramları, biyolojik olarak insana verilen ile sosyal olarak inşa edilen yönlerine vurgu yapması ile birbirinden ayrılmaktadır. Böylece ideal kadının pasif, sadık ve itaatkâr olarak tasviri de değişmiş oldu. Toplumsal cinsiyet meselesi yeniden şekillenirken, kadın cinsiyetiyle ilişkisi nedeniyle annelik de sorgulanmaya başlamıştır. Bu gereksinimleri karşılayan kadınlar "iyi” anneler olarak etiketlenirken, olmayanlar "kötü" olarak etiketleniyor. Toplumsal cinsiyet ve annelikteki bu değişimler, kadınların günlük yaşamda farklı şekillerde karakterize edilmelerine yol açmış ve bu

Dr. Öğr. Üyesi, Karamanoğlu Mehmetbey Üniversitesi, Edebiyat Fakültesi, İngiliz Dili ve Edebiyatı ABD (Karaman, Türkiye), serapsaribas@kmu.edu.tr, ORCID ID: 00oo-0002-4079-8024 [Araştırma makalesi, Makale kayıt tarihi: 31.12.2022-kabul tarihi: 20.02.2022; DOI: 10.2900o/rumelide.1074524]

Adres | Address

RumeliDE Dil ve Edebiyat Araştormaları Dergisi Osmanağa Mahallesi, Mürver Cicegi Sokak, No:14/8

Kadıköy - ISTANBUL / TÜRKIYE 34714 e-posta: editor@rumelide.com

RumeliDE Journal of Language and Literature Studies Osmanağa Mahallesi, Mürver Çiçeği Sokak, No:14/8

Kadıköy - ISTANBUL / TURKEY 34714

tel: $+905057958124,+902167730616$

e-mail: editor@rumelide.com,

phone: +90 $5057958124,+90216773$ o 616 
kadınlar yeni oluşturulan kadın imgelerine özel bir vurgu yapılmak suretiyle edebiyatta tasvir edilmeye başlanmıştır. Dikkatsiz, kötü ve sorumsuz annelerle anneliğin değişen yüzünü gösteren romanlar ve oyunlar da ortaya çıkmıştır. Bununla birlikte, geleneksel bir kadını ve anneyi temsil eden edebi eserler hala mevcuttur. Edebiyatta, geleneksel kadınlık ve anneliğin temsili bile farklılı gösterir, zira bazı yazarlar bu kadınları zayıflıklarını, yaşadıkları baskıyı ve kırılganlıklarını ortaya çıkarmak için kullanırken, diğerleri geleneksel bir kadının ve annenin çocuklarına nasıl güçlü, özverili ve şefkatli olabileceğini gösterme noktasında edebi yeteneklerini kullanırlar. Finlandiya'nın tanınmış edebiyatçılarından Elias Lönnrot, halk hikâyelerinden derleyip kaleme aldığı epik destanı Kalevala ile; Türk edebiyatının en dikkat çekici yazarlarından Yaşar Kemal ise ünlü İnce Memed romanı ile "kadın" ve "anne" kimliklerine karşı tamamen farklı tutumlar ortaya koymaktadır. Bu makalenin amacı Kemal'in İnce Memed'de kadınlığı ve anneliği olumlu bir şekilde tasvir ederken Lönnrot'un ise Kalevala'da küçümseyici bir bakış açısı sergilediğini göstermektir. Birbirinden farklı yazar ve dönemlerden günümüze ulaşan bu iki başyapıtın analizi, Anadolu ve Finlandiya kültürleri açısından farklılıklar göstermektedir.

Anahtar kelimeler: Anadolu Kültürü, Fin Folkloru ve Mitolojisi, Kadın Karakterler

\section{Introduction}

The writer Yashar Kemal is a prime representative of Turkish and exclusively Anatolian culture as portrayed in Anatolia's villages. Guzine Dino (1986, p. 267) indicates the prominence of Kemal's works as follows: "The most important and clearly the most popular to come out of the village culture was Yashar Kemal's which has had, and continues to have, numerous printings in Turkey and in many other countries, giving the Turkish novel a world-wide audience”. In his novel, Memed, My Hawk (2005), Kemal describes Chukurova and the villages around it, with a focus on Deyirmenoluk, the village where the protagonist Memed resides. He examines life in this Anatolian village with emphasis on cultural elements such as traditions, folk songs, and customs. Beyond these elements, he also epitomizes the traditional Anatolian woman: strong, patient, decisive and compassionate. He portrays these ideal female characters so emphatically that the reader understands the important of these concepts in their entirety.

Elias Lönnrot published a compilation of Finnish folklore and mythology titled The Kalevala in 1835 . Lönnrot begins his epic with the creation of the world and introduces his hero, Väinämönen, and then carries on with the mythical events that constitute Finnish culture. In his compilation of The Kalevala, Lönnrot did not just collect folk poetry; he also added something from his imagination, thus creating a literary epic in the vein of Milton's Paradise Lost or Virgil's the Aeneid. Gay (1997) asserts: "Lönnrot did take the materials for his epic from Finnish tradition, but the making of the Kalevala was not an effort at preserving folk epic, it was a creative process that began with the collection and editing of the folk poetry that was its source and continued through the 1849 edition of the Kalevala" (p.63). In the portrayal of his characters, Lönnrot placed prominence on man as the creators of culture in the epic. Conversely, women are presented negatively as they are widely victims of men and are abused, raped and killed.

At the outset, Yashar Kemal did not draw a strict line between his female characters and mother figures since in Memed, My Hawk virtually all women are mothers excluding Hatche, who only experienced motherhood for a short time at the end. Kemal combines ancient Anatolian conventions with the tradition of motherhood which "has been worshipped in cults for at least 32,0oo years, and is therefore

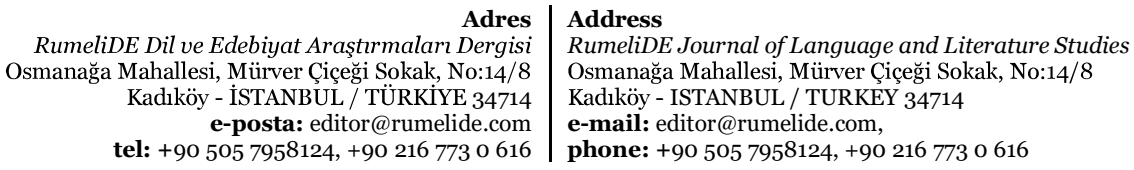


the oldest of ancient traditions" (Bockemühl, 2009, p. 63). In his introduction of a typical Anatolian woman, he stresses her motherhood, which is the highest emotional point that she can reach. Particularly on the Anatolian side of Turkey, "motherhood is considered the proper role for women, and being a mother is presented as both a socially and individually desirable goal" (Önal, 2011, p. 86). Kemal depicts this beautifully in Hatche's development as a woman who is raised to be a good wife and mother. Hatche's mother sends her to collect mushrooms in the mountains in an effort to teach her how to care for her family. When she is fifteen, Hatche goes to Memed's mother to learn how to knit traditional patterned stockings: "She knitted stockings and kerchiefs for Memed and invested songs over them, expressing her love, desire and jealousy in the colors of her embroidery and in the notes of her songs that are still sung throughout the Taurus" (Kemal, 2005, p. 71). It is apparent that Kemal offers women a paramount role in the construction of a culture whose songs are still sung in the region. At the end of the novel, Hatche decides to have Memed's child and gives birth to a son despite her difficult surroundings.

\title{
2. Yashar Kemal's Depiction of Female Characters
}

Aside from Hatche, all women in the Kemal's novel are mothers, yet Kemal does not utilize their warmheartedness, compassion, and love for their children as weaknesses. Rather, he presents a positive sentiment towards them. He achieves it so perfectly that when the novel is read, readers can associate themselves with those Anatolian mothers who are ready to sacrifice everything for their children. Deuneh, Memed's mother, is a prime example of Kemal's depiction of motherhood. She is a dedicated mother who loves her son much and is ready to do anything for him. When Memed runs away from Deyirmenoluk to Uncle Süleyman, Deuneh goes to the cruel Abdi Agha for help. She looks everywhere for her son like a madwoman, and begs everyone to help her find her son. In the search for Memed, the villagers find his harnessed oxen and his mother cries out thinking that her son is dead: "Deuneh was lost in grief. Shaking convulsively, she sank into the dust and lay there moaning. Her face and hair were soon white with dust, till her tears caked her grimy face" (Kemal, 2005, p. 27). When she returns home, she completely loses herself in grief, and gets very ill: "She had a burning fever. The young girls of the village nursed her, and after some days she rose from her sickbed, her eyes are all bloodshot. She tied a white cloth around her forehead as a sign of mourning" (Kemal, 2005, p. 28). Deuneh's health deteriorates both physically and mentally as the days pass without any news of Memed:

\begin{abstract}
Every morning Deuneh rose at dawn, went to the spring, and stared all day at the water. After ten days of this, utterly exhausted, she shut herself up in her house. Then another idea had entered her mind. Again, she rose at dawn, but now she climbed onto the roof and stared all day at the sky. Whenever she saw a flight of eagles hovering afar, she set off at once in that direction. Sometimes the eagles were very far away, perhaps circling over Yaghmurtepe, a whole day's journey from the village, but Deuneh went there all the same (Kemal, 2005, p. 29-29).
\end{abstract}

After such a painful period of waiting, the moment Deuneh ascertains that Memed is alive, she becomes breathless and cannot speak at first. She cannot even be exasperated with her son, who gets Abdi Agha furious with his disappearance. In Memed's second escape with Hatche, Abdi Agha loses his mind since Hatche is engaged to his nephew, Veli. Abdi Agha and Veli come to beat Deuneh for her son's guilt, and Kemal portrays it so vividly that her pain touches the hearts of readers.

Whilst Abdi Agha and Veli abuse and torture her severely, she does not blame her son. Kemal equates Deuneh's extreme tenderness for Memed with Memed's devotion for his mother. While planning his escape, Memed is concerned about his mother as considers that Abdi Agha will hurt her because of his actions. As much as Memed's escape can be thought of negligence towards his mother's well-bring, he

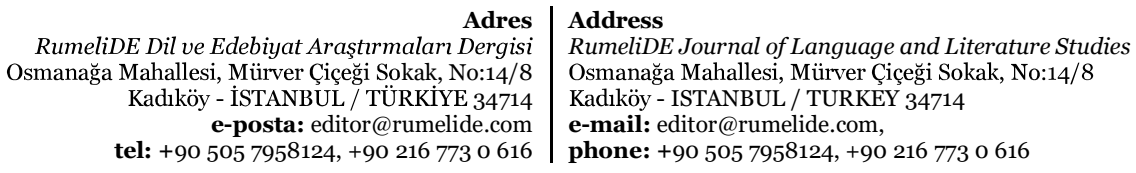


actually has the intention to save his mother from Abdi Agha's oppressive system by re-settling into another town together with her and Hatche.

Another notable female character in Memed, My Hawk is Iraz by virtue of her strength, decisiveness, and devotion to her ideals that make her completely an Anatolian woman. Her bitter story begins when she is widowed at the age of twenty with a nine-month-old baby in her arms. Despite her circumstance, she does not give up her struggle in life, and plows the land that her husband left to finish sowing their crops. Despite insistence from her husband's brothers, she refuses to marry one of them since she swore that she would not marry again, and feels strong enough to raise her child on her own. Although her uncles obtained possession her land and deprive Iraz of it, she finds ways to carry on: "In the summer she toiled in the fields of others, in the winter she worked as a servant in the homes of the rich. She managed to scrape through and her child grew to be a fine boy" (Kemal, 2005, p. 167). After her struggles to raise her child, Riza, she is devastated by the news of her beloved son's death. Upon seeing the corpse of her son, she bursts into tears and she loses herself in grief:

\begin{abstract}
Iraz was beating her breast and struggling piteously to contain her emotion. The other women tried to raise her from the corpse but she couldn't be dragged away. "Me too," she kept saying. "Bury me alive with my Riza". She lay on her son's dead body till nightfall. [...] The police dragged the woman, her eyes bloodshot and her face swollen from weeping, away from the body and pulled her to her feet, but she sank to the ground and remained motionless as if dead. For a long while she refused to move or utter a sound (Kemal, 2005, p. 171).
\end{abstract}

To avenge her son's death, Iraz is ready to anything, so she gets an axe and goes to Ruza's cousin's house to kill Ali. When she cannot find him, she sets their house on fire at night. Although she is arrested after this event, she exclaims: "My boy was worth a whole village, a whole country. Is it too much? Is it too high price?"(Kemal, 2005, p. 173). After the death of her son, Iraz seems to lose her life's purpose, which was to be the perfect mother for her son. Iraz's dedication to her son does not make her a passive mother figure; on the contrary, Kemal strengthens her with the feeling of motherhood and the reader sees a more powerful Iraz from now on. While in prison, Iraz directs her maternal love to Hatche and they become like mother and daughter there. Iraz's affection for Hatche is so great that she also accepts Memed as her son. She and Hatche save money for Memed and dream of living together side by side. Iraz compensates for the loss of her son through her love of Hatche and Memed. As a great mother, Iraz's nature wants to love, to dedicate herself to somebody. In the end, Iraz grabs Memed's child and accepts him as hers with care and nurture: "Brother, give me this child and let me go off to the villages around Antep. He'll die in these mountains. I've given up thinking of avenging Riza's blood. In my Riza's place there is this boy now. Give him to me and let me go. I'll bring up the boy" (Kemal, 2005, p. 365). Apart from her motherhood, Kemal stresses her cultural side together with Hatche. When they all live in the mountains, Hatche and Iraz set up a home there even in the worst conditions. This is an affirmation of the Turkish expression "yuvayı dişi kuş yapar" in English, 'men make houses, women make homes. The family had spent the whole winter in a cave, furnished it like a home, more pleasant than that of many a rich village Agha with its floor spread with pine needles over which they laid hand-worked nomad rugs, their colors suggesting spring: "[...] The walls of the cave were hung with the skins of big horned deer. The horns seemed to have been polished and the fur glistened like gold" (Kemal, 2005, p. 340-341). Apart from these talents, Iraz is also a healer. When Memed gets shot, she heals him and Memed recovers soon.

However, Iraz's most important features are her courage and strength, which makes her like a bandit fighting on Memed's side. When Captain Faruk fires at them, Iraz shoots back alongside Memed. Kemal's depiction of this strong Anatolian woman resembles Nene Hatun, a Turkish folk heroine, who

Adres $\mid$ Address

RumeliDE Dil ve Edebiyat Araşttrmalar Dergisi $\quad$ RumeliDE Journal of Language and Literature Studies Osmanağa Mahallesi, Mürver Çiçeği Sokak, No:14/8 Osmanağa Mahallesi, Mürver Çiçeği Sokak, No:14/8

Kadıköy - ÍSTANBUL / TÜRKIYE 34714 Kadıköy - ISTANBUL / TURKEY 34714 e-posta: editor@rumelide.com e-mail: editor@rumelide.com,

tel: +90 505 7958124, +90 2167730616 phone: +90 505 7958124, +90 2167730616 
grabbed her brother's gun and bravely went to fight in the Russo-Turkish war: "Iraz was more agile, a better shot and braver than the most renowned brigands. She could keep the guards at bay by herself for three whole days" (Kemal, 2005, p. 364). Iraz presents the picture of a strong and fearless Anatolian woman, a descendant of Nene Hatun and many brave unnamed Anatolian women who went to war by their men's side.

A final example of strong female characters in Kemal's novel is Hatche's mother, who is not as active a character as the others. At the beginning of novel, she is presented as a bad woman and mother: "She was a real termagant. Whatever quarrel or disturbance there might be in the village, she was always at the heart of it. A tall, strong woman, she attended to all the business of the house and even plowed the fields" (Kemal, 2005, p. 70). When she realizes her daughter's affair with Memed, she tries everything to keep her away from him: "Hatche's mother once caught them and punished her daughter. It was no use. Every evening she bound her hand and foot, but in vain. She put the lock after the lock on the door; Hatche found a way around every obstacle" (Kemal, 2005, p. 71). When she finds out that her daughter escaped with Memed, she curses her and believes that her daughter really killed Veli, her fiancé, so she does not visit her daughter in prison - an action which hurts Hatche the most. However, her "bad mother" image changes when she visits her daughter in prison and learns that she is not a killer. As a nurturer, she brings Hatche something to eat in prison. She feels sorry when Abdi Agha forbids her to visit Hatche, and whenever she finds a suitable time, she comes to see her daughter. She is totally changed now so that she brings news of Memed to her daughter. Although this action seems to cruel at first sight, Hatche's mother actually considers her child's well-being because of Memed's poor economic situation. As a mother, she thinks that her child deserves more, so she forbids Hatche to see Memed. However, in the end, she understands the great love between Hatche and Memed and supports them. Plainly, Kemal does not depict a negative women figure; he transforms every woman into a good mother and these mothers represent distinct aspects of a typical Anatolian woman in their own culture.

\section{Lönnrot's Depiction of Female Characters}

Elias Lönnrot draws a strict line between young women and mother figures in his epic. While the young female characters are fragile and weak, his mother characters are divided into two: strong and weak. Nevertheless, Lönnrot does not portray the strength of women positively as evidenced by the witch character: a strong female who is full of hatred towards the main male characters. Moreover, women do not contribute to the culture of Finland. Lönnrot gives this task to the male characters of the epic, who have supernatural forces that construct the cultural elements of Finland and arouse national feelings. As in many other mythologies from around the world, Lönnrot's epic begins with the creation of the world. The Virgin of the Air descends into the sea and forms the earth. After the creation of all on the earth, Air-daughter bears Väinämönen, the eternal bard. Väinämönen clears the earth, plants oak trees, and sows barley. On the surface, it seems Lönnrot ascribes creation to a female, however, it is the male character, the bard, who brings life to the world with his great power. It is clear that Lönnrot simply provides a stereotypical creation myth with a female at the centre, just as in the Greek, Roman, and Hindu mythologies.

The young female characters are depicted as weak in this epic due to their lust for the male characters. In the beginning of the epic, Joukhanainen, the young Lappish rival of the great bard, competes with Väinämönen and end up plunged into a swamp by the power of Väinämönen's words. To save himself, Joukhanainen offers his sister Aino to Väinämönen as compensation. In a very detailed way, he explains what his sister will do for him emphasizing her womanly duties for her husband: "I will yield my

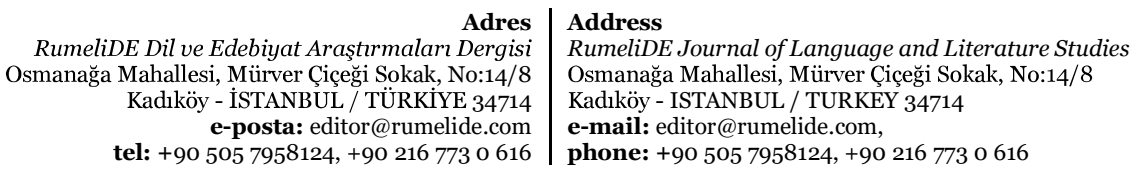


mother's child to clean out your hut and to sweep your floor rinse your wooden plates to wash out your cloaks weave your golden cloak bake your honey-bread" (Lönnrot, 2008, p. 35).

When Joukhanainen explains the situation to his mother and sister, his mother is overjoyed since she thinks that Väinämönen would make an excellent match for her daughter. However, Aino is depressed upon hearing the news since she does not want to marry such an old man. When Väinämönen woos her in the forest, she cannot endure it and unites with the sea by drowning herself.

Kylikki, the maiden of Saari Island, is kidnapped by the wicked and immoral Lemminkäinen, who woos and rapes many women. He coerces Kylikki to become his bride by swearing an oath that he will not go to war. Kylikki also swears that she will stop visiting and gossiping with her female friends. In the epic, Kylikki breaks their bond by visiting those girls and not obeying her husband. Lönnrot emphasizes Kylikki's unfaithfulness with Lemminkäinen's lack of trust for women: "I don't believe women's dreams nor the oaths of wives" (Lönnrot, 2008, p. 133).

This time wanton, Lemminkäinen sets off to woo the maiden of Northland and take her as his second wife, although his mother warns him that two brides are not for one bed. Another victim of men is Kullervo's own sister who is raped by her brother in the forest. Although Kullervo does not know that this girl is his sister and he is a little bit mentally deranged, he victimizes his own sister. Kullervo also kills Ilmarinen's wife to avenge the fact that she baked a stone into his bread. Ilmarinen cannot endure loneliness, so he creates a golden bride who is very beautiful, but she is silent, she cannot speak and thus lacks vitality. Other maidens in the epic are just entertainers and helpers of men in their sublime goals. It is clear Lönnrot does not give voice to his maidens but rather presents them weak characters destined to be the victims of men's lust, anger, and idiocy.

While Lönnrot's depiction of mother characters is contradictory since he portrays two different mother figures, both portrayals show his negative attitude towards woman. Louhi, the hag of Northland, is the most powerful female character in the epic with her endless struggle to beat the main male characters. Turunen, as cited in Sawin (1988), states that "Lönnrot garnered her name from one of the spirits in folk belief who are labelled for their particular arena of influence. 'Louhi' means 'causer of diseases" (p.196) In contrast to Kemal's powerful mother figure who is strong, compassionate, and altruistic, Lönnrot shows the power of woman negatively in The Kalevala (Siikala, 2004, p. 2). Sawin (1988,) suggests that Louhi is a complicated figure: "Lönnrot's Louhi appears to be essentially a cruel and manipulative mother, since she will marry off her unwilling daughter in return for money though at other times, she is confusingly compassionate and supportive of the maid's desire to choose her own husband" (p. 197) Actually, Louhi's attempts to choose the best husband for her daughter are misrepresented by Lönnrot because she does not force her daughter into marriage, in the end her daughter marries the man who she really loves. By setting some tasks for those men, Louhi wants to see who loves her daughter the most and is willing to do anything for her. However, "Louhi's attempts to protect her daughters from the men's depredations are treated as wilful and culpable, not as motherly" (Sawin, 1988, p. 206). Louhi's bride-price should not be misinterpreted since although she asks a precious gift for her daughter's marriage, it is not for herself. When Väinämönen offers her gold and silver for the mistress, Louhi rejects: "I don't ask for your gold coins nor do I want your silver: Gold coins are children's playthings silver coins are horse trinkets. If you can forge the Sampo beat out the bright-lid from a swan's quill tip a barren cow's milk from one barley grain the wool of one ewe I'll give you a girl" (Lönnrot, 2008, p. 76).

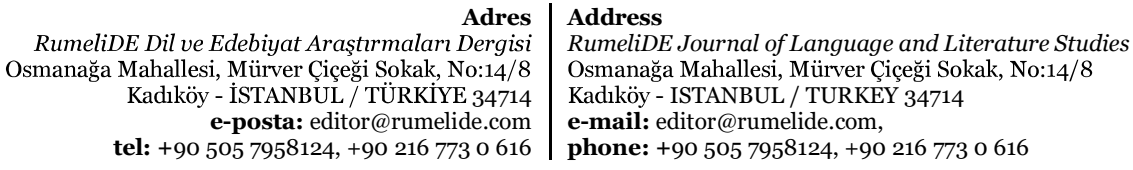

tel: $+905057958124,+902167730616$ 
Louhi does not look for money; she wants the Sampo, which is source of fertility in the land. Ilmarinen states the Sampo's importance for the land in the epic: "With the Sampo in Northland! There is ploughing, there sowing there are all kinds of growing there is good luck for ever." (Lönnrot, 2008, p. $514)$.

Louhi's bride-price is not for her own benefit rather for the benefit of her country, Northland. When Väinämönen, Ilmarinen, and Lemminkäinen come to Pohjola to take the Sampo back, Louhi does everything in her power to prevent them. As a witch, she is very powerful; she can use the power of words like the male characters. For the blood-feud of her husband, she calls the men to war: "Louhi, mistress of Northland called Northland together: She armed the crowd with their crossbows equipped the men with their swords; she made ready the North's crafts prepared the war-boat mustered the men in her ship prepared the warriors" (Lönnrot, 2008, p. 562).

In the war that she initiates, Louhi steals the flame like Prometheus, sends diseases and wild animals over them, and lastly steals the sun and the moon to bury them into darkness. However, she is defeated by the men; she surrenders at the end of the epic and gives the sun and the moon back to humankind. By taking the Sampo from Louhi's hands, Lönnrot gives one of the most important cultural elements of Finland back to men again. Lönnrot clearly represents Louhi negatively despite her great strength and magic skills.

Although she is not given a name in the epic, Lemminkäinen's mother is another of Lönnrot's important figures. She is only identified by the name of her son despite her great capacity for resurrection. She is the advice-giver to her egotistic and foolish son, although he never listens to her advice. With her maternal senses, she feels the death of her son and finds his corpse in the river. She rakes the pieces of her son's body out of the Tuonela River, puts them back together, and brings her son back to life. As a woman, her body has "potential as a source of life", but she gives life to her child for the second time (Bockemühl, 2009, p. 55). Karkala, cited in Swain, states that "she is probably the only woman in the Western literary tradition to represent woman as man's resurrection, in contrast to Eve: woman as man's downfall" (Sawin, 1988, p. 206). Although Lönnrot creates the image of a powerful mother, this character remains an anonymous woman willing to do anything to serve men in any way. Sawin (1988, p. 206) claims that in Lönnrot's work "only virgins and mothers, women who act to produce the patriarchy and remain fully under the men's control, are evaluated positively. Women who want to retain control over their own sexuality and alternative knowledge are condemned as whores, witches or monsters".

\section{Conclusion}

Consequently, discrimination against women in The Kalevala is made most evident through women's exclusion of the creation of culture. The cultural hero is Väinämönen as he is the one who brings life to the world, creates iron and other important metals, hunts the national animals of Finland such as elk, deer and bear, plays the national instrument kantele, and performs folk music creating the Finnish culture. Moreover, Ilmarinen the skilful smith forges the Sampo, the magic mill that brings fertility and good luck to the land. Ilmarinen also contributes to the creation of Finnish culture while women characters are simply represented as typical women who are busy with their daily chores. Lönnrot gives them many tasks to accomplish such as cleaning, cooking, plowing, and serving their husbands and husbands' families. He diminishes the value of women by making them busy with common things.

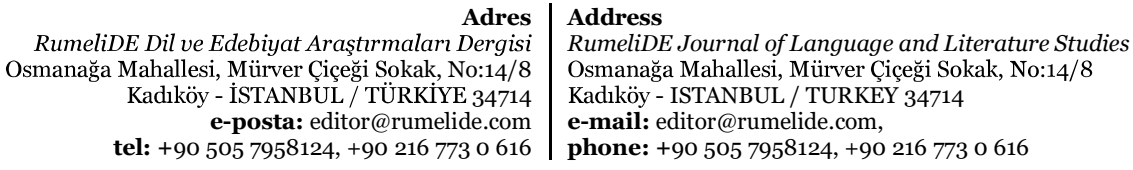

RumeliDE Dil ve Edebiyat Araștormalart Dergisi e-posta: editor@rumelide.com tel: +90 505 7958124, +90 2167730616
Address

Osmană̌a Mahallesi,

e-mail: editor@rumelide.com,

phone: +90 $5057958124,+902167730616$ 
While Yashar Kemal creates strong female characters in his novel Memed, My Hawk, Elias Lönnrot represents weaker females in his epic The Kalevala. In Kemal's novel, traditional Anatolian women are presented as strong, compassionate and patient characters that get stronger with the power of motherhood. Like the Anatolian heroines of folklore, together with their men, they overcome hardships. Also, women's role in the construction of Anatolian culture shows Kemal's positive attitude towards them. However, Lönnrot creates a negative image of women and mothers in his work. He presents weak female characters that are victimised by men and contradictory mother figures. Sawin (1988) states that under the control of Lönnrot, "Lemminkäinen's mother is extolled as devoted mother, while Louhi is condemned as an evil witch" (p. 207). In addition to these negations, he does not give any space to women in the construction of Finnish culture. Obviously, there is a huge gap between the two writers considering the representation of women in their specific works.

\section{References}

Arendell, T. (1999). Mothering and motherhood: A decade review. University of California.

Bockemühl, A. (2009). A woman's path: Motherhood, love, and personal development. Rudolf Steiner Press.

Butler, J. (1986). Sex and gender in simone de beauvoir's second sex. Yale French Studies. 72, 35-49.

Choi, P., Henshaw, C., Baker, S., \& Tree, J. (2005). Supermum, superwife, supereverything: performing femininity in the transition to motherhood. Journal of Reproductive and Infant Psychology, $23(2), 167-180$.

Dino, G. \& Grimbert, J. (1986). The Turkish peasant novel, or the Anatolian theme. World Literature Today, 6o(2), 266-275.

Gay, D. E. (1997). The creation of the Kalevala. Jahrbuch für Volksliedforschung, 42, 63-77.

Kemal, Y. (2005). Memed, My Hawk. New York Review Books.

Lönnrot, E. (2008). The Kalevala. Oxford University Press.

Önal, L. (2011). The discursive suppression of women: Female evils as the villains of the motherhood narrative. Folklore, 48, 85-116.

Sawin, P. E. (1988). Lönnrot's brainchildren: The representation of women in Finland's Kalevala. Journal of Folklore Research, 25(3), 187-217.

Siikala, A. L. (2004). The many faces of contemporary folklore studies. The Folklore Fellows, 27, 2-23.

RumeliDE Dil ve Edebiyat Araşttrmaları Dergisi Osmanağa Mahallesi, Mürver Çiçeği Sokak, No:14/8

Kadıköy - İSTANBUL / TÜRKIYE 34714 e-posta: editor@rumelide.com tel: +90 $5057958124,+902167730616$
Address

RumeliDE Journal of Language and Literature Studies

Osmanağa Mahallesi, Mürver Çiçeği Sokak, No:14/8

Kadıköy - ISTANBUL / TURKEY 34714

e-mail: editor@rumelide.com,

phone: +90 5057958124, +90 2167730616 